ATTHULAB:

Islamic Religion Teaching $\mathcal{E}$ Learning Journal

Volume 4 Nomor 2 Tahun 2019

الطلاب

http://journal.uinsgd.ac.id./index.php/atthulab/

\title{
Bimbingan orang tua dalam mengembangkan kepribadian anak
}

\author{
Jamaluddin'), Acep Komarudin'), dan Asep Andi Rahman ${ }^{3)}$ \\ Jurusan Pendidikan Agama Islam \\ Universitas Islam Negeri Sunan Gunung Djati Bandung \\ Jalan Soekarno Hatta Kota Bandung Jawa Barat 40629 Indonesia \\ 1)Email: jamaluddin@uinsgd.ac.id \\ 2)Email: acepkomarudin@uinsgd.ac.id \\ 3)Email: andirahman@uinsgd.ac.id
}

\begin{abstract}
The family as the first and foremost educational institution, its existence determines the child's future. With no serious attention and full affection from both parents especially, then of course in turn it will be difficult to grow and develop mental and mental health of children who are healthy and normal, which ultimately affects the child's personality itself. The emergence of problems of deviant behavior in children and adolescents is a picture of the effects of the failure of parental guidance at home. One form of concern the Putrajawa government for this matter in collaboration with PKM UIN Sunan Gunung Djati Bandung team will provide a training in parental guidance in developing children's personality. The method of activities in the training in the form of seminars and discussions and seminar simulations are given to participants in order to provide knowledge and understanding on how to guide appropriate child development. The material will be presented as many as six materials ranging from concepts to implementation. The results of this training can be declared successful. This can be seen from: (1) the attendance of participants in accordance with the target of $92 \%$ (2) the results of the training were declared very good. (3) Participants are very enthusiastic about participating in the training which is seen from the seriousness in participating in the training.
\end{abstract}

$$
\begin{gathered}
\text { Keywords: } \\
\text { parental guidance; personality; child }
\end{gathered}
$$

\begin{abstract}
Abstrak: Keluarga sebagai lembaga pendidikan yang pertama dan utama, keberadaannya menentukan masa depan anak. Dengan tanpa perhatian yang serius dan kasih sayang yang penuh dari kedua orang tua terutama, maka sudah barang tentu pada gilirannya akan sulit terjadi pertumbuhan dan perkembangan jiwa dan mental anak yang sehat dan normal, yang akhirnya sangat berpengaruh terhadap kepribadian anak itu sendiri. Munculnya permasalahan perilaku menyimpang pada anak dan remaja merupakan gambaran dari efek gagalnya bimbingan orang tua di rumah. Salah satu bentuk kepedulian pemerintah Putrajawa terhadap hal tersebut bekerja sama dengan tim PKM UIN Sunan Gunung Djati Bandung akan memberikan sebuah pelatihan bimbingan orang tua dalam mengembangkan kepribadian anak. Metode kegiatan dalam pelatihan berupa seminar dan diskusi serta simulasi seminar diberikan kepada peserta dalam rangka memberikan pengetahuan dan pemahaman tentang bagaimana membimbing perkembangan anak yang tepat. Materi yang akan disajikan sebanyak enam materi mulai dari konsep sampai implementasi. Hasil pelatihan ini dapat dinyatakan berhasil. Hal ini dapat dilihat dari: (1) kehadiran peserta sesuai dengan target yaitu 92\% (2) hasil pelatihan dinyatakan sangat baik. (3) Peserta sangat antusias mengikuti pelatihan yang dilihat dari keseriusan mengikuti pelatihan.
\end{abstract}

\author{
Kata Kunci: \\ bimbingan orang tua; kepribadian; anak
}

DOI: http://dx.doi.org/10.15575/ath.v4i2.5575

Received: 08, 2019. Accepted: 10, 2019. Published: 11, 2019 


\section{PENDAHULUAN}

Orang tua dalam bahasa pendidikan dikenal dengan keluarga. Keluarga merupakan suatu lembaga pendidikan yang pertama dan utama, yang eksistensinya sangat menentukan akan masa depan kehidupan anak. Keluarga merupakan suatu wadah dan tempat persemaian tumbuh dan berkembangnya anak-anak (keluarga) secara keseluruhan. Oleh karena itu, suatu kehidupan keluarga inti yang terdiri dari seorang ayah bersama istrinya merupakan pusat paling awal dan sangat menentukan dalam proses pembinaan, pendidikan dan pembentukan kepribadian anak sejak dini.

Di sinilah anak pertama kalinya memperoleh pengalaman dan sentuhan pendidikan, baik secara fisik maupun secara moral spiritual, yang pada gilirannya pengalaman-pengalaman itu akan sangat mewarnai corak kehidupan kepribadiannya di masa-masa selanjutnya. Karena segala sesuatu yang pernah dialami oleh anak semasa kecil (dalam kandungan) itu akan tertanam di dalam jiwanya (rohaninya) sedemikian kuat.

Sebagaimana salah seorang tokoh di bidang pendidikan dan ilmu psikologi perkembangan di masa Romawi kuno, bernama Quintilianus dikatakan bahwa 'kesankesan yang diperoleh anak ketika masih kecil akan tertanam secara mendalam dan menjadi milik abadi di dalam jiwanya (Imam Bawani, 1990:52).

Beberapa penelitian yang dikemukakan oleh beberapa ahli, seperti yang dikemukakan dalam majalah rumah tangga dan kesehatan bahwa "orang tua berperan dalam menentukan hari depan anaknya. Secara fisik supaya anak-anaknya bertumbuh sehat dan berpostur tubuh yang lebih baik, maka anak-anak harus diberi makanan yang bergizi dan seimbang. Secara mental anak-anak bertumbuh cerdas dan cemerlang, maka selain kelengkapan gizi perlu juga diberi motivasi belajar disertai sarana dan prasarana yang memadai. Sedangkan secara sosial agar anak-anak dapat mengembangkan jiwa sosial dan budi pekerti yang baik mereka harus diberi peluang untuk bergaul mengaktualisasikan diri, memupuk kepercayaan diri seluas-luasnya. Bila belum juga terpenuhi biasanya karena soal teknis seperti hambatan ekonomi atau kondisi sosial orang tua." (Sabri Alisuf, 1995:24).

Dengan demikian keluarga berarti mempunyai peranan yang tidak kecil dalam membentuk jiwa dan kepribadian seorang anak, karena baik buruknya pribadi dan jiwa anak sangat tergantung dari keluarga atau kedua orang tuanya. Kalau keluarga selalu menanamkan nilai-nilai yang baik ke dalam jiwa anak, tentu anak cepat atau lambat akan pasti memiliki pribadi dan jiwa yang baik pula, sebaliknya kalau keluarga tidak menanamkan nilai-nilai yang baik, maka sudah tentu pribadi dan jiwa anak akan menjadi tidak baik pula (Imam Bawani, 1990:52).

Keluarga merupakan salah satu bagian yang sangat penting bagi kelangsungan kehidupan anak dan merupakan lingkungan atau rumah yang pertama sekali dikenal oleh anak. Keluargalah (kedua orang tua) yang bertanggung jawab memenuhi segala tuntutan dan kebutuhan anak, baik kebutuhan biologis maupun kebutuhan psikologis. Suasana aman, tenteram, bahagia dan damai serta keserasian hubungan harmonis antara ayah dan ibu hendaknya senantiasa terpancar di lingkungan ini, karena dengan suasana demikianlah anak-anak akan dapat memperoleh rasa kasih sayang dan sentuhan perhatian yang diharapkannya (Mustafa Fahmi, 1977:72).

Lingkungan keluarga sangat mempengaruhi bagi pengembangan kepribadian anak dalam hal ini orang tua harus berusaha untuk menciptakan lingkungan keluarga yang sesuai dengan keadaan anak. Dalam lingkungan keluarga harus diciptakan suasana yang serasi, seimbang, dan selaras, orang tua harus bersikap demokrasi baik dalam memberikan larangan, dan berupaya merangsang anak menjadi percaya diri. 
Pendapat lain tentang peran dan tugas orang tua adalah sebagai berikut, "Komunikasi ibu dan ayah dalam keluarga sangat menentukan pembentukan pribadi anak-anak di dalam dan di luar rumah. Selanjutnya dikatakan bahwa seorang ayah umumnya berfungsi sebagai dasar hukum bagi putra-putrinya, sedangkan seorang ibu berfungsi sebagai landasan moral bagi hukum itu sendiri." (Ali, 1995:30).

Dengan tanpa perhatian yang serius dan kasih sayang yang penuh dari kedua orang tua terutama, maka sudah barang tentu pada gilirannya akan sulit terjadi pertumbuhan dan perkembangan jiwa dan mental anak yang sehat dan normal, yang akhirnya sangat berpengaruh terhadap kepribadian anak itu sendiri.

Munculnya permasalahan perilaku menyimpang pada anak dan remaja merupakan gambaran dari efek gagalnya bimbingan orang tua di rumah. Kesibukan orang tua, permasalahan rumah tangga, perceraian dan rendahnya pengetahuan orang tua dalam membimbing anaknya menjadi problem tersendiri dalam pembentukan kepribadian anak.

Hal itu pun yang terjadi di masyarakat Desa Putrajawa. Desa Putrajawa, merupakan sebuah wilayah desa yang secara administrastif berada di wilayah Kecamatan Selaawi Kabupaten Garut. Masyarakat di desa ini secara umum bermata pencaharian bertani dan buruh tani, sebagian kecil dari penduduk desa ada yang menjadi PNS, Polisi, dan TNI, sebagian dari kaum muda mencari nafkah dengan merantau ke kota menjadi buruh pabrik, berdagang, dan jasa. Aspek pendidikan masyarakat Desa Putrajawa rata-rata SMA, dan kurang dari 2\% lulusan perguruan tinggi.

Visi dari Desa Putrajawa adalah membangun masyarakat desa berkualitas dan membangun komunikasi masyarakat sekitar dalam meningkatkan sumber daya manusia. Memiliki luas wilayah 7.691 hektar, dengan jumlah penduduk saat ini 7011 jiwa, ada 5300 hak pilih, meliputi 3 dusun, 9 RW 34 RT dengan jarak tempuh ke Kabupaten Garut 35 Kilometer.

Tingkat ekonomi masyarakat Desa Putrajawa masih tergolong rendah, hal itu dipengaruhi faktor pendidikan dan keterampilan yang mereka miliki masih rendah, sehingga daya beli masyarakatpun masih rendah. Aspek keagamaan masyarakat Desa Putrajawa dapat dikategorikan dalam tiga kelompok, pertama kelompok santri dan kyai, Kelompok masyarakat umum, dan kelompok kaum muda. Kehidupan keberagamaan masyarakat Desa Putrajawa juga dipengaruhi oleh ORMAS keagamaan yang bukan hanya sebagai wadah organisasi tapi lebih menjadi sebagai ideologi. Tingkat frekuensi kegiatan keagamaan di Desa Putrajawa cukup tinggi, dari mulai kegiatan majlis taklim, peringatan hari Besar Islam, acara-acara keagamaan lainnya yang sering dilaksanakan.

Jika dilihat dari kondisi sosio kultur masyarakat Desa Putrajawa, orang tua (keluarga) di Desa Putrajawa dalam memberikan bimbingan terhadap anak-anaknya sangat lemah. Pendidikan yang rendah sangat berkorelasi dengan pengetahuan dan pemahaman orang tua terhadap pola bimbingan mereka terhadap anak. Hal ini menjadi salah satu faktor tidak tepatnya orang tua dalam mendidik dan mengembangkan kepribadian anaknya. Banyaknya tingkat pengangguran, penggunaan narkoba di kalangan muda, dan munculnya hubungan di luar nikah merupakan efek yang diakibatkan kesalahan dalam bimbingan orang tua di Desa Putrajawa.

Permasalahan-permasalahan di atas menuntut kepada pemerintahan setempat, para tokoh agama dan masyarakat untuk bersama-sama membangun lingkungan yang lebih mendorong pada peningkatan kepribadian generasi muda, hal itu dapat dilakukan dengan memberikan pengetahuan dan pemahaman kepada masyarakat sebagai orang 
tua dalam membimbing kepribadian anak yang lebih tepat. Salah satu bentuk kepedulian pemerintah Putrajawa terhadap hal tersebut bekerja sama dengan tim PKM UIN Sunan Gunung Djati Bandung akan memberikan sebuah pelatihan bimbingan orang tua dalam mengembangkan kepribadian anak.

\section{METODE PENELITIAN}

Metode kegiatan dalam pelatihan berupa seminar dan diskusi serta simulasi seminar diberikan kepada peserta dalam rangka memberikan pengetahuan dan pemahaman tentang bagaimana membimbing perkembangan anak yang tepat. Materi yang akan disajikan sebanyak enam materi mulai dari konsep sampai implementasi. Diskusi ini diberikan dalam menggali dan memperluas pemahaman dan wawasan peserta serta sharing pengetahuan antar peserta tentang membimbing perkembangan anak. Sebagai puncaknya maka dilaksanakan simulasi.

\section{HASIL PENELITIAN DAN PEMBAHASAN}

\section{A. Realita Pemahaman Orang Tua terhadap Perkembangan Psikologi Anak}

Sejatinya anak merupakan harapan setiap orang tua dan keluarga. Berbicara tentang permasalahan anak, yang terjadi akhir-akhir ini mengundang perhatian "serius" dari setiap kalangan. Belum lagi kasus demi kasus yang dialami anak akhir-akhir ini, cukup menguras sisi emosional setiap individu yang mendengarnya.

Di samping itu semua, hal yang akan berdampak pada anak dan menjadi satu bagian yang sangat penting, yang mungkin luput dari perhatian para orang tua, pengasuh, bahkan guru adalah pemahaman tentang sisi psikologis anak. Lalu pertanyaan selanjutnya; Ini menjadi tugas siapa? Tugas ibunya, ayahnya, neneknya, pengasuhnya, gurunya di sekolah, atau psikolog/profesional anak?

Berdasarkan hasil olah data, terhadap jawaban dari pertanyaan yang diberikan kepada peserta sebelum dilaksanakan kegiatan Pengabdian kepada Masyarakat, bimbingan orang tua dalam mengembangkan kepribadian anak, menunjukkan lemahnya pemahaman orang tua terhadap perkembangan psikologi anak. Pada materi tentang perkembangan psikologi anak, panitia memberikan 3 pertanyaan, yaitu: a) Batasan usia anak; b) Tugas ciri-ciri perkembangan anak; c) Sikap orang tua terhadap anak.

Dari tiga poin yang dijadikan materi pertanyaan, diketahui bahwa masyarakat di Desa Putrajawa secara umum mereka masih kebingungan tentang batasan anak dari usia berapa? Dari 60 peserta yang hadir 10\% menjawab batasan usia anak adalah 0-12 tahun, 20\% menjawab usia anak itu antara 0-6 tahun, 70\% menjawab usia anak itu antara 6-15 tahun.

Pertanyaan ini diberikan, karena pengetahuan dan pemahaman orang tua terhadap batasan usia anak, akan sangat berpengaruh terhadap sikap dalam memperlakukan anak. Ternyata masih banyak orang tua yang memperlakukan anaknya tidak sesuai dengan perkembangan psikologinya.

Terhadap materi pertanyaan kedua, yaitu apa saja tugas dan ciri dari usia anak?. Pada umumnya peserta tidak memberikan jawaban, hanya 10 orang yang menjawab dan itupun tidak tepat. Ini menunjukkan kebingungan orang tua, apa sebenarnya tugas dan ciri-ciri dari perkembangan psikologi pada anak.

Hal ini sangat wajar, karena tingkat pendidikan peserta umumnya adalah SMP dan tingkat motivasi membaca masyarakat di Desa Putrajawa secara umum masih rendah. 
Materi ketiga, yang menjadi pertanyaan pada tes pra PKm, adalah sikap mereka terhadap anak, pertanyaannya adalah: Bagaimana sikap anda jika anak sering bertanya tentang sesuatu?

$75 \%$ menjawab kesal dan menyuruh diam, 20\% menjawab senang dan berusaha menjawab pertanyaan anak, dan $10 \%$ dari peserta menjawab kadang dibiarkan dan kadang dijawab.

Dari data tersebut menunjukkan secara umum orang tua masih kebingungan dalam bersikap terhadap perilaku anak, salah satunya jika anak banyak bertanya. Secara umum mereka kesal dan menyuruh diam kepada anak. Hal ini dipengaruhi oleh pengetahuan dan pemahaman mereka terhadap perkembangan usia anak, serta kebingungan menjawab pertanyaan anak.

Seperti disampaikan oleh ibu Kokom, dia menyatakan bingung untuk menjawab pertanyaan anak yang kadang susah dijawab, oleh karena itu lebih baik dia menyuruh diam kepada anaknya. Hal itu diperkuat oleh ibu Imas, yang juga bersikap sama terhadap anaknya.

Tiga materi pertanyaan yang diberikan pada pre test, cukup memberikan gambaran bagi tim PKm, bahwa Realita Pemahaman Orang Tua terhadap Perkembangan Psikologi Anak di Desa Putrajawa masih rendah dan ini akan sangat berpengaruh terhadap bimbingan orang tua dalam mengembangkan kepribadian anak.

\section{B. Pelatihan Bimbingan Orang Tua dalam Mengembangkan Kepribadian Anak}

Latar Belakang: Berdasarkan hasil olah data pada kegiatan pre test, yang menyimpulkan bahwa lemahnya pemahaman orang tua terhadap perkembangan psikologi anak, yang mempengaruhi pada sikap orang tua dalam memberikan bimbingan pengembangan kepribadian anak, menjadi dasar Pengabdian Kepada Masyarakat Desa Putrajawa difokuskan pada pemberian pelatihan Bimbingan Orang Tua dalam Mengembangkan Kepribadian Anak.

Tujuan: Tujuan dari pelatihan adalah, 1) Terwujudnya masyarakat yang faham tentang perkembangan psikologi anak; 2) Terbentuknya masyarakat yang memiliki pengtahuan tentang pola bimbingan orang tua dalam mengembangkan kepribadian anak.

Tahapan Pelaksanaan: Secara umum pelaksanaan pelatihan ini terdiri atas tiga tahap:

1) Orientasi dan observasi, Pada tahap orientasi dan observasi, tim melakukan komunikasi dengan pihak pemerintah desa Putrajawan tentang pola bimbingan orang tua terhadap perkembangan kepribadian anak. Kemudian disepakati pentingnya untuk melaksanakan pelatihan, dan penentuan peserta dalam pelatihan. Pada pertemuan awal peserta diberikan gambaran kegiatan yang akan dilaksanakan, kemudian mereka di berikan pree test seperti di sampaikan hasilnya di atas.

2) Pemberian Materi, Pada tahap ini, peserta diberikan materi dari narasumber yang disiapkan dengan materi pelatihan sebagai berikut: Materi I (Anak dalam Perspektif Psikologi Perkembangan); Materi II (Bimbingan Orang Tua dalam Mengembangkan Kepribadian Anak); Materi III (Mengenal Potensi Anak); Materi IV (Potensi Anak pengaruhnya terhadap pola bimbingan orang tua).

3) Evaluasi, Setelah pemberian materi, kemudian peserta diberikan evaluasi berupa tes tulis, dengan menjawab sebanyak 10 pertanyaan. Pertanyaan-pertanya tersebut terkait dengan materi yang sudah disampaikan narasumber, serta beberapa pertanyaan aplikatif, sebagai indikator pemahaman peserta dalam 
mengimplementasikan materi terhadap pola bimbingan orang tua terhadap perkembangan kepribadian anak.

Tindak Lanjut: Untuk memperkuat hasil pelatihan, maka tim melakukan tindak lanjut, dengan memberikan tugas lapangan kepada peserta, berupa isian tentang pola bimbingan mereka terhadap anak dalam mengembangkan kepribadiannya. Lembar isian dikumpulkan setelah 1 minggu pelaksanaan pelatihan.

\section{Peran Orang Tua dalam Pengembangan Kepribadian Anak}

Mengenai materi tentang peran orang tua dalam mengembangkan kepribadian anak, tim melakukan wawancara dengan peserta setelah pelaksanaan PKm. Berdasarkan hasil wawancara inilah, tim mendapatkan berbagai gambaran kemajuan berfikir dan pemahaman masyarakat Desa Putrajawa (Khususnya peserta) tentang posisi, peran dan fungsi dia bagi anak-anaknya.

Kepribadian mandiri pada diri anak adalah idaman seluruh orang tua. Secara hakiki, perkembangan kemandirian seseorang dilakukan secara bertahap sesuai dengan tingkat kebutuhan pada hidupnya. Pemahaman kepribadian mandiri ini haruslah dilakukan secara terus-menerus dengan cara pemberian nasehat dan dimusyawarahkan dengan anak serta menggunakan kata-kata yang dimengerti oleh anak dalam proses orang tua membimbing dan mengawasi anak, hal itu diungkapkan dalam wawancara dengan Ibu Cucu.

Hal lain yang harus dilakukan orang tua agar anak dapat menjadi pribadi mandiri selain memberi nasehat atau musyawarah adalah cara mengawasi dan membimbing anak menurut Ibu Siti agar anak tidak salah dalam menganggapi nesehat, seperti contoh ketika orang tua berkata, "nak, kamu harus memiliki kepribadian yang mandiri agar kelak kamu bisa berdiri sendiri dan tidak menyusahkan orang lain", kalimat ini ambigu sehingga anak berfikir maksudnya "aku harus melakukan apa-apa sendiri tanpa menyulitkan orang lain termasuk kedua orang tua", disini tugas orang tua harus benar-benar mengawasi anak jangan sampai anak menjadi salah dalam menerima pemahaman.

Hal ini pun kembali ditegaskan oleh Ibu Nurlaela dalam wawancara dengan penulis, dari nasehat yang diberikan oleh orang tua anak akan mengekspresikannya dengan kebiasaan-kebiasaan kepribadian mandiri, karena orang tua bukan hanya sebagai panutan namun sebagai pendidik dalam segala bidang kehidupan anak.

Ibu Tini Martini (sebagai Ketua PKK Desa Putrajawa) menyampaikan dengan cara demikian anak lebih akan menjadi pribadi mandiri misalnya dengan bangun pagi tanpa harus dibangunkan, mengerjakan pekerjaan rumah (pr) tanpa harus diperintah ataupun diminta, serta dapat menjalankan ibadah-ibadah seperti sholat secara tepat waktu, puasa di bulan ramadhan, puasa sunah serta sedekah di setiap harinya.

Membentuk kepribadian mandiri pada anak tidaklah begitu sulit ketika orang tua mampu memahami anak dan pemberian nasehat yang baik serta penanaman intelektual sebagai daya dukung untuk membantu menanamkan kepribadian mandiri pada anak. Melalui nasehat dan penanaman nilai intelektual tentang kemandirian, anak akan mampu menyerap dan mengerti tujuan ataupun maksud dari kedua orang tuanya.

Ibu Apong (peserta dari Bobos) memberikan pernyataan dalam wawancara dengan penulis bahwa dalam hal pemberian nasehat orang tua harus dapat memperhatikan serta menyesuaikan waktu yang tepat dan sesuai dalam pemberian nasehat dan pemberian pemahaman pada anak seperti pada di waktu santai keluarga dan di saat suasana hati anak merasa gembira dan senang. Ibu Wati pun sependapat dengan memberikan pernyataan yang sudah penulis catat bahwa orang tua tidak dapat menunggu waktu tepat ini tiba melainkan orang tua haruslah menciptakan suasana 
tersebut setiap hari, kebisaan-kebiasaan tersebut akan membiasakan anak untuk dapat mengeksplorasi emosional diri, berpendapat sesuai hatinya dan membagi keluh kesahnya di segala aktifitasnya setiap hari.

Ibu Rosita (dari Kebon Jeruk), mengatakan orang tua harus mengerti anak sebelum memberikan pemahaman tentang pengajaran kepribadian mandiri, oleh karena itu sesering mungkin orang tua harus mengajak anak untuk sharing, berbagi keluh kesah dan pendapat, dengan demikian anak merasa dihargai oleh kedua orang tuanya. Menurut Ibu Nina paling menyukai jika orang tua memuji serta membanggakan apalagi jika memberikan pujian berupa kata-kata yang baik. Bersikap saling menghargai dan berbagi selain mengakrabkan ialah mengetahui atau memahami satu sama lain dengan lebih efektif dalam mengurangi kesalahpahaman antara orang tua dan anak.

Ibu Siti Hasanah (dari Kp. Putrajawa) pun memberikan tanggapan dalam wawancaranya bahwa membuat anak menjadi pribadi mandiri dapat pula dimulai dengan membuat anak berfikir mandiri akan keuangannya sendiri, orang tua sebagai panutan dapat memberikan pemahaman misal tentang kedisiplinan menabung akan berdampak baik pada anak hal ini akan membuat anak termotivasi dan akan mulai berfikir untuk menabung hal ini pun efektif untuk membuat anak mandiri dalam bidang keuangannya.

Menurut Ibu Momoh (dari Sinar Sari) orang tua tidak hanya bertindak sebagai panutan dengan hanya memberikan pemahaman namun orang tua harus secara langsung mencontohkan pada anak.

\section{Teknik Pengembangan Kepribadian Anak Mandiri}

Hasil wawancara dengan peserta, tentang cara mengembangkan kepribadian anak agar menadiri, tim PKm dapat mengkategorisasikan teknik yang dipahami dan dilakukan masyarakat dalam mengembang kepribadian anak, diantaranya:

\section{Orang tua memberi bekal keterampilan untuk mengurus diri sendiri}

Orang tua memberikan bekal keterampilan untuk mengurus diri sendiri dengan cara pembiasaan-pembiasaan yang dilakukan setiap hari di rumah dan orang tua sebagai contoh bagi anak. Sebelum orang tua mengajarkan kepada anak pentingnya mengurus diri sendiri, orang tua harus terlebih dahulu mencontohkan kepada anak, seperti: orang tua mencontohkan setelah makan peralatan makan dibersihkan dan dikembalikan ke tempat semula. Jadi melalui kebiasaan yang dilakukan setiap hari dan orang tua sebagai contoh bagi anak maka akan membuat anak lebih mudah menerapkan sikap mandiri dalam kehidupan serta ia lebih memahami pentingnya sikap mandiri bagi dirinya dan orang lain.

Ibu Herawati, menyampaikan bahwa setelah mengikuti pelatihan bimbingan orang tua dari UIN Sunan Gunung Djati Bandung, ia menyadari tentang kesalahan dalam pola asuh anak, terutama dalam pengembangan diri anak. Dia sering menyuruh sesuatu tetapi tidak memberikan contoh kepada anak, sehingga anak sering melawan dan enggan untuk melakukannya. Contoh misalnya dia menyuruh anaknya shalat, tapi ia belum shalat. Jawaban anak kadang balik nanya, "upami mamah atos teu acan??" (Kalo mamah sudah belum).

Ibu Yeni Nuraeni (Kader dari Kp. Cihaseum), menguatkan bahwa, "leres putra abdi ge kitu, naon anu dilakukeun ku abdi diconto ku anjeuna" (benar anak saya juga begitu, apa yang saya lakukan dicontoh oleh anak saya).

Dua pernyataan peserta ini, menggiring pada sebuah pemahaman bahwa, kemandirian anak dikeluarga dapat terbentuk dan lebih efektif melalui metode contoh yang sudah menjadi kebiasaan orang tuanya di rumah, oleh karena itu maka orang tua 
harus memiliki keterampilan pengetahuan diri baik menyangkut dengan perkembangan anak, dan pengetahuan tentang kehidupan yang sesuai dengan aturan norma dan agama.

2. Orang tua membentuk kegiatan yang merangsang sikap mandiri kepada anak

Anak sudah ada sifat mandiri pada dirinya namun perlu ditimbulkan dengan orang tua harus kreatif dalam menentukan kegiatan yang tepat dalam menanamkan sikap mandiri pada anak, kemudian orang tua mempersiapkan media yang akan digunakan dalam kegiatan tersebut, misalnya: kegiatan yang dilakukan untuk merangsang tumbuhnya sikap mandiri pada anak adalah kegiatan menanam bunga, Pertama, orang tua menjelaskan terlebih dahulu tata cara kegiatan yang akan dilaksanakan, kemudian setelah orang tua memberikan penjelasan, anak disuruh menyelesaikan tugas menanam bunga. Anak diajarkan untuk menyelesaikan tugasnya sendiri tanpa bantuan dari orang lain. "Ibu dan aku sering menanam bunga bersama, aku lebih suka menanam bunga matahari karena cantik", wawancara dengan Anggun Pratiwi, penulis dapat mengetahui bahwa dengan kegiatan yang merangsang kemandirian anak juga menambah kedekatan emosional orang tua dan anak.

\section{Orang tua menerapkan pembiasaan yang positif}

Orang tua menerapkan pembiasaan yang positif dengan cara orang tua membiasakan anak untuk melakukan kegiatan yang baik dan berguna serta orang tua sabagai contoh yang baik bagi anak, misalnya: orang tua mencontohkan kepada anak bahwa sebelum dan sesudah makan harus berdo'a terlebih dahulu, shalat berjamah tepat waktu dan lain sebagainya.

4. Orang tua memberanikan anak bertanggung jawab atas pilihannya sendiri

Dilakukan dengan cara mengajarkan kepada anak untuk bertanggung jawab dari hal-hal yang sering dilakukan sehari-hari oleh anak. Seperti: anak memiliki dua barang yang sangat ingin dibeli namun orang tua hanya mengizinkan membeli satu barang, ketika anak memilih barang A maka anak harus bertanggung jawab dengan menjaga dan memeliharanya.

\section{Orang tua memberikan kebebasan kepada anak untuk menentukan tujuannya sendiri}

Menurut Ibu Hasanah, orang tua sebagai panutan harus menerapkan kebebasan kepada anak untuk menentukan tujuannya sendiri dengan cara: orang tua harus menentukan kegiatan apa yang akan dilakukan hari itu, orang tua menanyakan kepada anak tentang hal yang disenangi, misal anak ingin pergi piknik di taman. Hal ini juga akan memungkinkan anak untuk dapat mengembangkan kepercayaan pada dirinya serta dapat mengaktualisasi diri dengan baik.

\section{Menyadarkan anak bahwa pendamping tidak selalu ada di sisinya}

Menurut Ibu Trinawati, orang tua menyadarkan anak bahwa pendamping tidak selalu ada di sisinya dengan metode nasihat. Dengan nasihat tersebut anak dapat mengambil pesan positif bahwa tidak selamanya orang tua, saudara dan teman bisa selalu ada di samping anak, maka dari itu anak diajarkan untuk memiliki sikap mandiri dari dini agar sikap ketergantungan dengan orang bisa dihilangkan. Menyadarkan anak bahwa pendamping tidak selalu disampingnya bisa melalui media bercerita ketika anak menjelang tidur, Menurut Ibu Susi, anaknya mengatakan "lebih suka mendengarkan cerita ketika malam hari karena lebih mengerti yang dimaksud cerita, apalagi cerita anak-anak". Orang tua dapat memilih cerita misal tentang anak-anak yang berprestasi karena kemandirian yang dimiliki seperti kisah-kisah Rasullulah. 
Metode-metode yang digunakan oleh orang tua untuk membentuk kepribadian anak akan lebih menstrukturkan dalam membentuk jiwa mandiri pada diri anak. Ketika wawancara dengan Ibu Susan, beliau memberikan pernyataan bahwa: "membentuk anak yang berkepribadian mandiri tidak mudah namun tidak sulit juga tergantung orang tua karena orang tualah yang mengetahui kelebihan dan kekurangan anak dari hal itu orang tua dapat memulai menumbuhkan kepribadian mandiri pada anak".

\section{E. Faktor yang Mempengaruhi Pengembangan Kepribadian}

Ibu Meli memberikan pernyataan kepada penulis bahwa dalam pembentukan kepribadian anak ada dua faktor yang membentuknya pertama ialah faktor internal dan faktor eksternal. Berikut penulis narasikan hasil wawancara dengan Ibu Meli:

\section{Faktor Internal}

Faktor internal ini terdiri dari dua kondisi, yaitu kondisi fisiologis dan kondisi psikologis. Berikut penjelasan mengenai dua kondisi tersebut yaitu: a) Kondisi fisiologis, Kondisi yang berpengaruh pada fisiologis anak di antaranya yaitu pada keadaan tubuh individu, kesehatan jasmani dan jenis kelamin. Pada umumnya anak yang sakit lebih bersikap tergantung daripada anak yang tidak sakit. Pada waktu yang lama ketika anak sakit pada masa bayi menjadikan orang tua sangat memerhatikannya kondisi anak. Ketika anak yang menderita sakit atau lemah, maka secara langsung orang tua atau orang terdekat dari anak akan memberikan perhatian yang lebih intensif terhadap anak, sehingga anak mendapatkan pemeliharaan yang lebih, dan itu sangat berpengaruh terhadap pencapaian kemandirian mereka. b) Kondisi psikologis, Meskipun kecerdasan atau kemampuan kognitif seorang anak dapat diubah atau dikembangkan melalui lingkungan, namun pada kenyataannya faktor bawaan juga mempengaruhi pencapaian kemandirian terhadap keberhasilan lingkungan dalam mengembangkan kecerdasan serta kemampuan seorang anak.

\section{Faktor eksternal}

Faktor eksternal merupakan faktor yang berasal dari luar diri anak, yang meliputi melalui faktor dari lingkungan, rasa cinta dan kasih sayang orang tua terhadap anakanak. a) Lingkungan, Lingkungan merupakan faktor yang sangat mempengaruhi dalam pembentukan kemandirian anak. Salah satu lingkungan terkecil sebagai tempat pertama dalam pembentukan karakter bagi ialah lingkungan keluarga. Dalam kondisi lingkungan keluarga inilah seorang anak akan belajar berinteraksi dengan orang-orang terdekatnya. b) Rasa cinta dan kasih sayang, Pemberian rasa cinta dan kasih sayang orang tua terhadap anaknya juga dipengaruhi oleh status pekerjaan orang tua. Apabila orang tua, khususnya seorang ibu yang bekerja di luar rumah untuk mencari nafkah, akibatnya sang ibu tidak maksimal dalam melihat perkembangan anaknya setiap saat. Sementara seorang ibu yang berada di dekat anak akan selalu memberikan kasih sayang yang maksimal untuk melihat langsung perkembangan anaknya dan bisa mendidiknya secara langsung. Maka selayaknya orang tua dalam memberikan rasa cinta dan kasih sayang kepada anak hendaknya diberikan dengan cara sewajarnya karena hal itu dapat mempengaruhi mutu kemandirian anak. c) Pola asuh orang tua dalam keluarga, Lingkungan keluarga berperan penting dalam pembentukan karakter kemandirian. Pembentukan karakter kemandirian tidak terlepas dari peran orang tua dan pengasuhan yang diberikan orang tua terhadap anaknya. Pola asuh ayah dan ibu mempunyai peran nyata dalam membentuk karakter mandiri anak usia dini. Toleransi yang berlebihan, begitu pun dengan pemeliharaan yang berlebihan dari orang tua yang terlalu keras kepada anak dapat menghambat pencapaian kemandiriannya. Pengalaman dalam kehidupan pengalaman dalam kehidupan anak meliputi pengalaman di lingkungan sekolah dan 
masyarakat. Lingkungan sekolah berpengaruh terhadap pembentukan karakter anak, baik melalui hubungan dengan teman maupun dengan guru. Faktor budaya dan kelas sosial juga dapat mempengaruhi karakter anak usia dini. Dalam perkembangannya, anak mulai memisahkan diri dari orang tuanya dan mengarahkan kepada teman sebaya. Dengan demikian, melalui hubungan dengan teman sebaya, anak akan berfikir mandiri.

Setelah melakukan wawancara, penulis membagi atas dua faktor yang mempengaruhi pembentukan kepribadian anak yaitu faktor yang mendukung dan faktor penghambat. Dalam wawancara dengan Ibu Popon (Kader dari Kp. Burujul) menjelaskan bahwa ada empat faktor pendukung pembentukan kepribadian anak, yaitu: 1) Kecerdasan anak, 2) Bimbingan Orang Tua di rumah, 3) Lingkungan Masyarakat, dan 4) Tontonan TV.

Di bawah ini secara detail penulis narasikan hasil wawancara dengan Ibu Komala (Kader dari Kp. Putrajawa): a) Suasana hati anak, Suasana hati anak perlu dipertimbangkan oleh orang tua, karena anak masih belum banyak mengerti. Kata tidak setuju dan tidak disukai oleh anak hanya dapat kita mengerti jika anak menangis. Orang tua perlu memahami anak tidak bisa dipaksa namun anak bisa dibimbing, orang tua harus tahu kapan anak berada dalam suasana hati atau mood yang menyenangkan untuk dapat membentuk kepribadian yang mandiri. b) Lingkungan tempat tinggal, Ketika anak bergaul dengan anak yang memiliki kepribadan mandiri yang tinggi secara tidak langsung anak akan berpengaruh positif, begitu pula sebaliknya jika anak bersosialisasi dengan lingkungan yang memiliki kepribadian yang rendah. Orang tua harus dapat memberikan keluasan pada anak dalam bergaul dan bersosialisasi dengan lingkungannya, agar anak tidak merasa terkekang, namun dengan tetap melakukan pengawasan terhadap anak, hal ini dimaksudkan agar anak tetap dapat mengaktualisasikan diri terhadap keadaan sosial yang ada. c) Kecerdasan anak, Kecerdasan setiap anak berbeda-beda sesuai dengan asupan gizi (makanan), pola asuh dan pendidikan yang diberikan orang tua terhadap anak. Ketika orang tua memberi pemahaman pada anak tentang pentingnya mempunyai kepribadian yang mandiri anak mampu mengaktualisasi dengan baik. Contoh: anak akan mudah mengatasi masalahnya sendiri tanpa bantuan orang lain. d) Lembaga Pendidikan, Lembaga pendidikan akan berpengaruh pada segala bidang pada diri anak termasuk dalam memiliki kepribadian yang mandiri, karena di lembaga pendidikan ini merupakan salah satu bantuan orang tua untuk membentuk anak menjadi pribadi mandiri. e) Teman Sebaya atau sepermainan, Orang tua tidak boleh banyak mengekang anak untuk tidak bermain dan bersosialisasi dengan lingkungan namun orang tua dapat mengawasi dan membimbing anak. Teman sebaya adalah wadah anak untuk mengembangkan potensi kepribadian mandirinya.

Menurut Ibu Onyas (Kader dari Kp. Burujul) ada beberapa faktor yang menghambat orang tua dalam pembentukan kepribadian anak, di antaranya adalah: a) Komunikasi, Miss comunication (kesalahan pahaman) antara orang tua dan anak. Komunikasi dua arah yang kurang efektif antara orang tua dan anak. b) Waktu luang atau kesempatan, Ketidakmampuan orang tua dalam menciptakan dan memanfaatkan waktu berkumpul dengan anak akan berpengaruh pada tingkat kemandirian anak. Berikut hal-hal yang memicu hal tersebut: 1) Orang tua dan anak sibuk dengan urusannya sendiri. Seperti: orang tua sibuk dengan televisi dan berita, sedangkan anak sibuk dengan mainannya. 2) Biasanya orang tua terkhusus kepala keluarga "seorang bapak" pulang larut dan malam hari hanya dipergunakan untuk istirahat dari segala macam kepadatan kegiatan. 
Di samping itu anak yang mempunyai kemandirian yang tinggi akan memiliki stabilitas emosional dan ketahanan yang mantap dalam menghadapi tantangan dan tekanan. Teori Alferd Bandura yaitu anak mampu mengembangkan dan mengaktualisasi yang ada di dalam dirinya keluar dengan bantuan orang tua sebagai panutan dan uswatun khasanah bagi anak-anaknya. Bagi seluruh orang tua membentuk kepribadian anak adalah hal yang penting terkhusus kepribadian yang mandiri, dimana anak mampu berdiri sendiri, tidak bergantung pada orang lain, bersifat aktif dan kreatif dalam bersosialisasi dengan lingkungannya.

Pembentukan kepribadian mandiri sangat baik apabila diberikan semenjak usia anak, termasuk dalam wilayah formal, informal, maupun nonformal. Pembentukan kepribadian mandiri pada usia anak sangat memerlukan contoh sebagai modeling dan pembiasaan dalam kehidupan sehari-hari sebagai pembiasaan. Pendapat Zakiah Darajat sejalan dengan peran orang tua terhadap anak dalam membentuk kepribadian anak berbentuk: a) Peran sebagai motivator, di mana anak diberikan nasihat; b) Peran sebagai pengawas, melindungi anak baik jasmani dan rohani; c) Peran sebagai pembimbing, mendidik dengan berbagai ilmu pengetahuan; d) Peran sebagai panutan atau role model, memeliharan dan membentuk anak.

Pembentukan kepribadian mandiri pada anak diberikan melalui cara-cara yang sesuai dengan kondisi anak, misalnya bermain, bercerita, bercakap- cakap, dan pengalaman nyata. Adapun pada bab II yang sesuai adalah metode yang dapat dipergunakan oleh orang tua dalam membentuk kepribadian mandiri pada anaknya, yaitu: a) Orang tua memberi bekal keterampilan untuk mengurus diri sendiri, Orang tua memberikan bekal keterampilan untuk mengurus diri sendiri dengan cara pembiasaan-pembiasaan yang dilakukan setiap hari di rumah dan orang tua sebagai contoh bagi anak. Sebelum orang tua mengajarkan kepada anak pentingnya mengurus diri sendiri, orang tua harus terlebih dahulu mencontohkan kepada anak, seperti: orang tua mencontohkan setelah makan peralatan makan dibersihkan dan dikembalikan ke tempat semula. Jadi melalui kebiasaan yang dilakukan setiap hari dan orang tua sebagai contoh bagi anak maka akan membuat anak lebih mudah menerapkan sikap mandiri dalam kehidupan serta ia lebih memahami pentingnya sikap mandiri bagi dirinya dan orang lain. b) Orang tua membentuk kegiatan yang merangsang sikap mandiri kepada anak, orang tua harus kreatif dalam menentukan kegiatan yang tepat dalam menanamkan sikap mandiri pada anak, kemudian orang tua mempersiapkan media yang akan digunakan dalam kegiatan tersebut, misalnya: kegiatan yang dilakukan untuk merangsang tumbuhnya sikap mandiri pada anak adalah kegiatan menanam bunga, Pertama, orang tua menjelaskan terlebih dahulu tata cara kegiatan yang akan dilaksanakan, kemudian setelah orang tua memberikan penjelasan, anak disuruh menyelesaikan tugas menanam bunga. Anak diajarkan untuk menyelesaikan tugasnya sendiri tanpa bantuan dari orang lain. c) Orang tua menerapkan pembiasaan yang positif, orang tua menerapkan pembiasaan yang positif dengan cara orang tua membiasakan anak untuk melakukan kegiatan yang baik dan berguna serta orang tua sabagai contoh yang baik bagi anak, misalnya: orang tua mencontohkan kepada anak bahwa sebelum dan sesudah makan harus berdo'a terlebih dahulu, shalat berjamah tepat waktu dan lain sebagainya. d) Orang tua memberanikan anak bertanggung jawab atas pilihannya sendiri, Dilakukan dengan cara mengajarkan kepada anak untuk bertanggung jawab dari hal-hal yang sering dilakukan sehari-hari oleh anak. Seperti: anak memiliki dua barang yang sangat ingin dibeli namun orang tua hanya mengizinkan membeli satu barang, ketika anak memilih barang A maka anak harus bertanggung jawab dengan menjaga dan memeliharanya. e) Orang tua memberikan 
kebebasan kepada anak untuk menentukan tujuannya sendiri, orang tua menerapkan kebebasan kepada anak untuk menentukan tujuannya sendiri dengan cara: orang tua harus menentukan kegiatan apa yang akan dilakukan hari itu, orang tua menanyakan kepada anak tentang hal yang disenangi, misal anak ingin pergi piknik di taman. Hal ini juga akan memungkin anak untuk dapat mengembangkan kepercayaan pada dirinya. f) Menyadarkan anak bahwa pendamping tidak selalu ada di sisinya, orang tua menyadarkan anak bahwa pendamping tidak selalu ada di sisinya dengan metode bercerita ketika anak akan tertidur tentang pendamping tidak selalu ada di sisinya. Dengan cerita tersebut anak dapat mengambil pesan positif dari cerita bahwa tidak selamanya orang tua, saudara dan teman bisa selalu ada di samping anak, maka dari itu anak diajarkan untuk memiliki sikap mandiri dari dini agar sikap ketergantungan dengan orang bisa dihilangkan.

Berdasarkan uraian di atas, perkembangan anak untuk membentuk kepribadian mandiri dapat ditandai dengan memberi kebebasan untuk anak dalam melakukan segala sesuatunya dengan caranya sendiri, seperti misalnya bertanggung jawab mengerjakan pekerjaan rumah (pr), berdoa sebelum dan sesudah makan, mendirikan sholat lima waktu tepat waktu, aktif dan kreatif dalam lingkungan sosialnya dan lain sebagainya. Sangat mungkin walaupun anak yang masih muda tetapi ia dapat melakukan segala sesuatunya dengan sendiri tanpa kritik dan menjadikan anak merasa percaya diri dengan caranya tersebut.

Faktor internal dan faktor eksternal dalam pembentukan kepribadian mandiri anak sebagai berikut: a) Faktor internal merupakan faktor yang berasal dari dalam diri anak itu sendiri, meliputi emosi dan intelektual. Faktor emosi ini ditunjukkan dengan kemampuan mengontrol emosi dan tidak terganggunya kebutuhan emosi orang tua. Sementara faktor intelektual diperlihatkan dengan kemampuan untuk mengatasi berbagai masalah yang dihadapi. b) Faktor eksternal, yaitu faktor yang datang atau ada di luar anak itu sendiri. Faktor ini meliputi lingkungan, karakteristik, sosial, stimulasi, pola asuh, cinta dan kasih sayang, kualitas informasi anak dan orang tua, pendidikan orang tua dan status pekerjaan orang tua.

\section{F. Faktor Pendukung dan Penghambat Pengembangan Kepribadian}

Adapun hasil temuan peneliti berdasarkan keseluruhan data yang dikumpulkan bahwa ada faktor pendukung dan penghambat dalam pengembangan kepribadian anak.

\section{Faktor Pendukung}

Faktor pendukung ini berasal dari penggabungan faktor intern dan faktor ekstern dalam pembentukan kepribadian anak, antara lain: a) Suasana hati atau mood anak, suasana hati anak penting untuk dipahami oleh orang tua, karena pada dasarnya anak adalah individu yang polos dan tulus dalam menyatakan berbagai hal pada dirinya. Orang tua perlu memahami anak tidak bisa dipaksa namun anak bisa dibimbing, orang tua harus tahu kapan anak berada dalam suasana hati atau mood yang menyenangkan untuk dapat membentuk kepribadian yang mandiri yang ideal. b) Lingkungan tempat tinggal, lingkungan adalah faktor yang tidak bisa dihindarkan dalam pembentukan dan perkembangan kepribadian anak. Ketika anak bergaul dengan anak yang memiliki kepribadian mandiri yang tinggi secara tidak langsung anak akan berpengaruh positifnya, begitu pula sebaliknya jika anak bersosialisasi dengan lingkungan yang memiliki kepribadian yang rendah. Orang tua harus dapat memberikan keluasan pada anak dalam bergaul dan bersosialisasi dengan lingkungannya, agar anak tidak merasa terkekang, namun dengan tetap melakukan pengawasan terhadap anak, hal ini 
dimaksudkan agar anak tetap dapat mengaktualisasikan diri terhadap keadaan sosial yang ada. c) Kecerdasan anak, Kecerdasan setiap anak berbeda-beda sesuai dengan asupan gizi (makanan), pola asuh dan pendidikan yang diberikan orang tua terhadap anak. Ketika orang tua memberi pemahaman pada anak tentang pentingnya mempunyai kepribadian yang mandiri anak mampu mengaktualisasi dengan baik. Contoh: anak akan mudah mengatasi masalahnya sendiri tanpa bantuan orang lain. $\mathbf{d}$ ) Lembaga pendidikan, Lembaga pendidikan akan berpengaruh pada segala bidang pada diri anak termasuk dalam memiliki kepribadian yang mandiri. Lembaga pendidikan sudah menjadi teman anak bahkan sejak usia anak 5 tahun. Lembaga pendidikan ini merupakan salah satu bantuan orang tua untuk membentuk anak menjadi pribadi mandiri. Secara tidak langsung lembaga pendidikan mempengaruhi pembentukan kepribadian mandiri karena anak menghabiskan hampir seperempat harinya di sekolah atau lembaga pendidikan. e) Teman sebaya atau sepermainan, Teman sebaya adalah wadah anak untuk mengembangkan potensi kepribadian mandirinya. Orang tua tidak boleh banyak mengekang anak untuk tidak bermain dan bersosialisasi dengan lingkungan namun orang tua dapat mengawasi dan membimbing anak. Anak adalah individu meniru dimana ia akan meniru segalanya, semakin tinggi tingkat kemandirian teman sebaya akan membuat tinggi pula tingkat kemandirian anak. f) Motivasi dan nasehat dari kedua oang tua, Terbentuknya anak menjadi pribadi yang mandiri tidak lepas dari orang tua sebagai role model atau panutan bagi anak. Dari motivasi dan nasehat anak mendapat rangsangan untuk mandiri dalam segala aktivitasnya.

\section{Faktor Penghambat}

Faktor penghambat pembentukan kepribadian anak terbagi menjadi tiga, antara lain:

a) Miss Comunication (salah persepsi), komunikasi adalah hal mudah semua orang lakukan bahkan anak kecil pun dapat berkomunikasi dengan baik. Namun disinilah antara orang tua dan anak banyak terjadi miss comunication dimana jika ini terjadi akan berdampak besar bagi keakraban dalam keluarga. Anak tidak dapat menyesuaikan katakata dalam komunikasi pada orang tua, namun orang tua mampu melakukannya. Dalam membentuk kepribadian mandiri baik pemberian pemahaman maupun ajaran yang diberikan haruslah menggunakan kata-kata yang mudah dimengerti oleh anak sehingga anak akan mudah mengerti pula yang dimaksudkan oleh orang tuanya. b) Waktu luang atau kesempatan, waktu kebersamaan keluarga harus menjadi quality time bagi seluruh orang tua, karena waktu dan kesempatan tidak akan terulang. Luangkan waktu lebih banyak untuk anak dalam usaha membentuk anak menjadi pribadi mandiri.

c) Pengawasan dan bimbingan masih kurang, pengawasan dan bimbingan merupakan hal wajib yang harus dilakukan seluruh orang tua. anak dibiarkan untuk memilih dan bertanggung jawab atas pilihannya namun orang tua mesti mengawasi dengan pemberian arahan, bimbingan maupun konseling dengan anak.

\section{SIMPULAN}

Pelatihan-pelatihan yang dapat memberikan wawasan terhadap orang tua dalam membimbng anaknya sangat penting. Karena bimbingan orang tua sangat berpengaruh dalam mengembngkan kepribadian anak. Pengabdian Keapda Masyarakat yang telah dilaksanakan di Desa Putrajawa Kec. Selaawi Kab. Garut. Telah menggambarkan begitu hausnya masyarakat akan informasi dan pengatahuan yang berkaitan dengan pola bimbingan orang terhadap anak. Pengetahuan dan pemahaman orang tua terhadap psikologi perkembangan anak, potensi anak, dan pola pertumbuhan dan perkembangan 
anak, sangat berpengaruh terhadap sikap dan pola bimbingan orang tua dalam mengembangkan kepribadian anak. Faktor eksternal masih dianggap faktor pengahmabat utama orang tua dalam mengembangkan kepribadian anak di keluarga.

\section{REFERENSI}

Abdul Mujib. 2007. Kepribadian dalam Psikologi Islam. Jakarta: PT. Raja Grafindo Husada.

Ahmad Warson Munawwir. 1993. Al-Munawwir, Kamus Arab-Indonesia. Yogyakarta: Pondok Pesantren Karapyak.

Amier Daien Indrakusuma. 1975. Pengantar Ilmu Pendidikan. Malang: Usaha Nasional.

Anwar Sutoyo. 2014. Bimbingan dan Konseling Islam. Yogyakarta: Pustaka Belajar.

D. B. Helms \& J.S. Turner. 1983. Exploring Child Behavior. New York: Holt Rinehartand Winston.

Dini P. Daeng. 1996. Metode Mengajar di Taman Kanak-kanak. Jakarta: Depdikbud.

Elizabeth B. Hurlock. 1999. Perkembangan Anak. Jakarta: Erlangga.

Ernawulan Syaodih. 2004. Bimbingan di Taman Kanak-kanak. Jakarta: Dikti Depdiknas

Hasbullah. 2001. Dasar-dasar Ilmu Pendidikan. Jakarta: PT Raja Grafindo Persada.

J.P Chalpin. 2009. Kamus Lengkap Psikologi. Terj. Kartini Kartono, Judul Asli Dictionary Of Psychology. Jakarta: Rajawali Pers.

Kamrani Buseri. 2003. Antologi Pendidikan Islam dan Dakwah Pemikiran Teoretis Praktis Kontemporer. Yogyakarta: UUII Press.

Kartini Kartono. 1986. Psikologi Anak. Bandung: Alumni.

M. Enoch Markum. 2000. Anak Keluarga dan Masyarakat. Jakarta: Sinar Harapan.

M. Solehuddin. 1997. Konsep Dasar Pendidikan Prasekolah. Bandung: FIP UPI

Mahmud Muhammad Al-Jauhari dan Muhammad Abdul Hakim Khayal. 2005. Membangun Keluarga Qur'an. Jakarta: Amzah.

Mahmud Yunus. 1973. Kamus Arab-Indonesia. Jakarta: Yayasan Penyelenggara Penterjemah Penafsir Al-Quran.

Muzayin. 1997. Hubungan Timbal Balik Pendidikan Agama. Jakarta: Bulan Bintang.

Robert J. Havighurst. 1978. Human Development and Education. New York: Longmans Green and Co.

Sabri Jamilah Sanan dan H. Martinis Yamin. 2010. Panduan Pendidikan Anak Usia Dini. Jakarta: Gaung Persada Press Group.

Saiful Bahri Djamarah. 2014. Pola Asuh Orang Tua dan Komunikasi dalam Keluarga. Jakarta: Rhineka Cipta. 
Bimbingan orang tua dalam mengembangkan kepribadian anak

Samsul Munir Amin. 2010. Bimbingan dan Konseling Islam. Jakarta: Amzah.

Saparinah Sadli. 1986. Inteligensi, Bakat, dan Test IQ. Jakarta: Gaya Favorit Press.

Sarlito Wirawan Sarwono. 2005. Psikologi Sosial. Jakarta: Balai Pustaka.

Sri Lestari. 2012. Psikologi Keluarga. Jakarta: Kencana Predana Media Group.

Syamsu Yusuf L.N. 2000. Psikologi Perkembangan Anak dan Remaja. Bandung: Remaja Rosdakarya.

Umar Tirtarahardja. 2005. Pengantar Pendidikan: Jakarta: Rineka Cipta.

WJS Purwadarminto. 1998. Kamus Umum Bahasa Indonesia. Jakarta: Balai Pustaka

Zakiah Darajat, dkk. 1996. Ilmu Pendidikan Islam. Jakarta: Bumi Aksara.

Zufan Saam. 2013. Psikologi Konseling. Jakarta: PT Graha Grafindo Persada. 